\section{Colour the birds red}

A remarkably keen ornithologist dwelt in a traditional "birds and bees" interpretive program for several years. He glided through the forest, visualizing myriads of feather-patterns, hearing symphonies of pharnages; he rejoiced in the spring, summer and fall of birds. He could see all life through birds; all parks could be ranked on an avian checklist. To the eyes of this man trees were bird-brown, the rising sun feather-red, the lake blue as the drake mallard's head. He had a point of view.

Give a park superintendent crayons and ask him to draw his park. He will take the black crayon and trace the boundary of the park first - always in plan view - and thus give physical reference to the imaginary line that few park visitors will even explore. His drawing will always be oriented to the most intensively maintained public beach, although no details will be shown on the beach's expanse. Urge him along (he may fret a bit, trying to get it right) and watch him carefully describe his park's skeleton. He will likely choose another crayon for his drawing's backbone, the park's road system. Certainly this is the feature he knows best. He has driven it in winter storms and summer sunsets; he has pursued a tired course along it late at night, looking for rowdies. If you tell him you want the finest details, he will draw in the culverts and the curves which go into washboard after a rain. With another coloured crayon he will site the comfort stations on his plan, and the campgrounds and boatlaunching ramps. Did he forget the park office building, the gate house, the beach safety-buoys, the amphitheatre? These facilities should be discrete shapes on his plan. He knows their location very well, because he developed them himself.

What does the park visitor see of a park or park system? No one really knows, of course. Park visitors are rarely the subject of attitudinal surveys, and management spends very little efforts in trying to communicate with park clientele. It is probably fair to say that most Canadians could not name more than five parks under provincial or federal jurisdiction in Canada. Of these parks, they likely would not be certain whether they were under one jurisdiction or another, and consequently could not clearly describe the parks' goals and objectives. Few park visitors would see a public park system extending beyond their own region, if at all, although they may increasingly be seeing private systems like Kampgrounds of America. Clearly, of course, there are many kinds of park visitors. The trailer-towing tourist looking for cheap accommodation and highway pull-offs for picnics and snapshots; the baby who uses the first three feet of wet beach to a depth of four inches, and sits on daddy's natural environment campsite, bored to tears in the hazy maze of green and blue and earthly browns; the unpaired twelve- to thirty-year-olds looking for weekend mates; the paired up youth seeking a place to play Tarzan and Jane.

Park visitors include a great number of people, perhaps the majority, parading to parks in a crusade of neo-nostalgia trying to rediscover a nearly forgotten environment their farmer father knew. What do these people see?

In your administrative offices you talk about park systems, but to the highway traveller you have no particular system at all. Your annual reports describe acreage amassed or reserved, yet the park visitor sees only the developed portions of the park; visitors rarely understand or vicariously experience the great expanse of Canada's parklands. Many park administrators work long hours for parks, because they truly believe in the goals of their parks. Yet instead of communicating these earnestly-held goals to the public, they order their men only to post the regulations against bad behaviour. Is it any wonder that park administrators complain of low budgets and poor public favour? The park agencies are talking to themselves!

At approximately the lowest level in park organizations across Canada - and noticeably lacking altogether in several agencies - resides the interpreter. His job is to interpret the environment to park visitor, to carry an understanding of the agencies' goals and objectives to the public, to act as an ear for the agency, and very often to perform as its environmental conscience. He is there to turn the public on to a park, to convey its identity, to give mum and dad and the kids some inspiration.

Often interpreters are regarded warily by management. They often are critical of management, after all; and in my view their criticism is part of what they're paid for. Often interpreters themselves are defensive, because they're hired as experts, and for a long time they flounder. It takes time and lots of patience to make a good interpreter. Probably many interpreters are, like many park managers, incompetent. To some of them an interpretive program is only the sum of its parts - statistics on nature trails, park museums, evening programs. But many interpreters are excellent; and Ontario has a disproportionate number of excellent interpreters. Most interpreters, unfortunately, are regarded as accessories to campsites: build the park, then hire an interpreter if you've got the money. This kind of thinking comes from minds dangerously susceptible to losing sight of the forest for the campsites and comfort stations, and forgetting the people for whom wilderness is preserved.

If your objective is to provide for meaningful recreational experiences, you must have a wellplanned interpretive program. If you are charged with operating a park system, you must have a strongly-integrated interpretive program. If you would try to conduct a constant, sensitive discussion with park visitors, you must make a sincere committment to an interpretive program. If you want children, young women and old men to colour in the birds when they remember your park, you must build a well staffed interpretive program.

Gary Sealey 